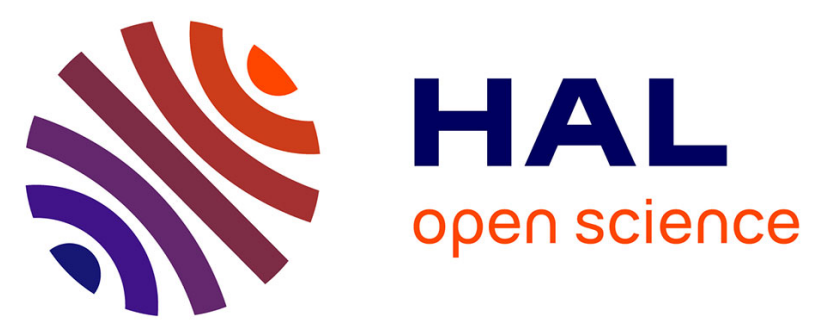

\title{
Efficient Visible-Light-Driven CO 2 Reduction by a Cobalt Molecular Catalyst Covalently Linked to Mesoporous Carbon Nitride
}

Bing Ma, Gui Chen, Claire Fave, Lingjing Chen, Ryo Kuriki, Kazuhiko Maeda, Osamu Ishitani, Tai-Chu Lau, Julien Bonin, Marc Robert

\section{To cite this version:}

Bing Ma, Gui Chen, Claire Fave, Lingjing Chen, Ryo Kuriki, et al.. Efficient Visible-Light-Driven CO 2 Reduction by a Cobalt Molecular Catalyst Covalently Linked to Mesoporous Carbon Nitride. Journal of the American Chemical Society, 2020, 142 (13), pp.6188-6195. 10.1021/jacs.9b13930 . hal-02954112

HAL Id: hal-02954112

https://hal-univ-paris.archives-ouvertes.fr/hal-02954112

Submitted on 30 Sep 2020

HAL is a multi-disciplinary open access archive for the deposit and dissemination of scientific research documents, whether they are published or not. The documents may come from teaching and research institutions in France or abroad, or from public or private research centers.
L'archive ouverte pluridisciplinaire HAL, est destinée au dépôt et à la diffusion de documents scientifiques de niveau recherche, publiés ou non, émanant des établissements d'enseignement et de recherche français ou étrangers, des laboratoires publics ou privés. 


\title{
Efficient Visible-Light-Driven $\mathrm{CO}_{2}$ Reduction by a Cobalt Molecular Catalyst Covalently Linked to Mesoporous Carbon Nitride
}

\author{
Bing Ma, Gui Chen,* Claire Fave, Lingjing Chen, Ryo Kuriki, Kazuhiko Maeda, Osamu Ishitani,* \\ Tai-Chu Lau,* Julien Bonin, and Marc Robert*
}

\begin{abstract}
Achieving visible-light-driven carbon dioxide reduction with high selectivity control and durability while using only earth abundant elements requires new strategies. Hybrid catalytic material was prepared upon covalent grafting a Co-quaterpyridine molecular complex to semiconductive mesoporous graphitic carbon nitride $\left(\mathrm{mpg}-\mathrm{C}_{3} \mathrm{~N}_{4}\right)$ through an amide linkage. The molecular material was characterized by various spectroscopic techniques, including XPS, IR, and impedance spectroscopy. It proved to be a selective catalyst for $\mathrm{CO}$ production in acetonitrile using a solar simulator with a high $98 \%$ selectivity, while being remarkably robust since no degradation was observed after 4 days of irradiation (ca. 500 catalytic cycles). This unique combination of a selective molecular catalyst with a simple and robust semiconductive material opens new pathways for $\mathrm{CO}_{2}$ catalytic light-driven

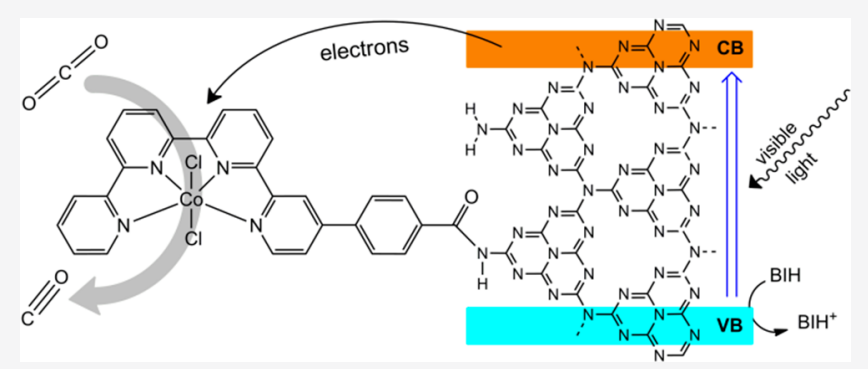
reduction.

\section{INTRODUCTION}

$\mathrm{CO}_{2}$ may be used as a renewable feedstock for making fuels or commodity chemicals directly from sunlight energy. But achieving photochemically driven conversion of $\mathrm{CO}_{2}$ remains a grand challenge, especially if one considers that only abundant materials should be used in view of future large scale applications. One approach consists of associating a molecular catalyst, typically a metal complex, to a robust semiconductive material that will efficiently absorb visible-light photons and transfer energy under the form of electrons to the catalyst. In this connection, carbon nitride $\left(\mathrm{C}_{3} \mathrm{~N}_{4}\right)$ is a synthetic polymer which received considerable attention in the past 15 years, not only as an earth-abundant visible-light photocatalyst ${ }^{1-3}$ for water splitting, ${ }^{4-6} \mathrm{CO}_{2}$ reduction, ${ }^{7}$ and inclusion in fuel cells ${ }^{8,9}$ but also for applications in organic synthesis, ${ }^{10}$ water depollution, ${ }^{11}$ or sensors. ${ }^{12}$ This medium band gap (ca. $2.8 \mathrm{eV}$ for the mesoporous phase) $)^{13,14}$ semiconductor possesses several allotropic phases, including $\alpha$-, $\beta$-, cubic, quasi-cubic, and graphitic phases, the latter (g$\mathrm{C}_{3} \mathrm{~N}_{4}$ ) being the most stable. ${ }^{15} \mathrm{~g}_{-} \mathrm{C}_{3} \mathrm{~N}_{4}$ is a graphite-like layered structure composed of conical nitrogen bridges and triazine or heptazine rings. It has high chemical stability, a good electron-withdrawing structure, and visible light response activity.

Since the pioneering work of Lehn on $\mathrm{Re}$ and $\mathrm{Ru}$ complexes, ${ }^{16-18}$ the photochemical reduction of $\mathrm{CO}_{2}$ with a molecular catalyst has proven to be a powerful way to target a specific product, ${ }^{19}$ from two-electron-reduced products (CO, formate) to fuels such as methane (eight-electron reduc- tion $)^{20-22}$ and to reach a high selectivity thanks to the control of the chelating environment and the steric and electronic effects of the ligands. Most of these molecular catalysts, including those based on earth-abundant transition metals such as $\mathrm{Fe}$ or $\mathrm{Mn}$, mainly lead to the formation of carbon monoxide or formate. ${ }^{23,24}$ However, molecular systems could suffer from progressive structural degradation due to photochemical instability or secondary reactions from/with byproducts. Bimolecular reactions (between the catalyst, the sensitizer, and the electron donor/acceptor) may additionally severely limit catalytic performances of homogeneous systems. To date, only a few semiconductor solid catalysts (e.g., metal oxides such as $\mathrm{TiO}_{2}$ ) have been reported for visible-light-driven catalysis, $^{23,25,26}$ and most of them suffer from poor catalytic selectivity, mainly because of the competition with hydrogen evolution. For all of these reasons, an attractive option is to combine an efficient and selective molecular catalyst with a solid-state sensitizer material such as carbon nitride. It may be achieved by adsorption or by covalent linking, so as to integrate the main components for the photochemically induced $\mathrm{CO}_{2}$ conversion. ${ }^{27,28}$ Several recent studies have reported the combination of various types of $\mathrm{C}_{3} \mathrm{~N}_{4}$ materials 
with a metal complex, ${ }^{29}$ for example, based on $\mathrm{Ru},{ }^{30-33} \mathrm{Ni}^{34}$ or $\mathrm{Co}^{14,35,36}$ for photochemical catalysis. To date, the best catalytic performance with mesoporous mpg- $\mathrm{C}_{3} \mathrm{~N}_{4}$ for $\mathrm{CO}_{2}$ reduction to formate was obtained with a trans- $(\mathrm{Cl})-\left[\mathrm{Ru}\left[4,4^{\prime}-\right.\right.$ $\left(\mathrm{CH}_{2} \mathrm{PO}_{3} \mathrm{H}_{2}\right)_{2}-2,2^{\prime}$-bipyridine $\left.](\mathrm{CO})_{2} \mathrm{Cl}_{2}\right](\mathrm{RuP})^{37}$ immobilized complex in a mixed DMA:TEOA $(4: 1, \mathrm{v}: \mathrm{v})$ solvent. The turnover number $\left(\mathrm{TON}_{\text {formate }}\right)$ reached 1061 after $20 \mathrm{~h}$ irradiation, with a selectivity of ca. $80 \%$. With regard to $\mathrm{CO}_{2}$ reduction to $\mathrm{CO}$, the best performance for systems only containing abundant elements was recently obtained by $\left[\mathrm{Fe}\left(2,2^{\prime}: 6^{\prime}, 2^{\prime \prime}: 6^{\prime \prime}, 2^{\prime \prime} \text {-quaterpyridine qpy) }\left(\mathrm{H}_{2} \mathrm{O}\right)_{2}\right]^{2+}(\mathrm{Fe}-\right.$ (qpy) $)^{38}$ as a homogeneous catalyst in a mixed ACN:TEOA $(4: 1, \mathrm{v}: \mathrm{v})$ solvent, $\mathrm{TON}_{\mathrm{CO}}$ reaching 155 along with a very high selectivity (97\%) and a high apparent quantum yield (ca. $4.2 \%$ ). Poisoning of the iron catalyst with $\mathrm{CO}$, however, hampers the long-term activity. The cobalt analogue, Coqpy, has also been shown to act as a selective and efficient homogeneous catalyst for the $\mathrm{CO}_{2}$-to- $\mathrm{CO}$ photochemical reduction when sensitized by the tris(bipyridine)ruthenium(II) $\left(\mathrm{Ru}(\mathrm{bpy})_{3}\right)^{2+}$ complex, with longer stability than $\mathrm{Fe}$ (qpy). ${ }^{39}$ To have a system incorporating only earth-abundant elements and to also enhance electronic interaction between the sensitizer and the catalytic sites, we have constructed a new molecular-material hybrid upon covalently attaching the metal complex Coqpy-Ph-COOH to the semiconductive polymer $\left(\mathrm{mpg}-\mathrm{C}_{3} \mathrm{~N}_{4}\right)$ through an amide linkage (Scheme 1). This

Scheme 1. (A) Preparation of the Coqpy@mpg- $\mathrm{C}_{3} \mathrm{~N}_{4}$ Hybrid Assembly and (B) Illustration of the Visible-LightDriven $\mathrm{CO}_{2}$ to $\mathrm{CO}$ Reduction Process ${ }^{a}$

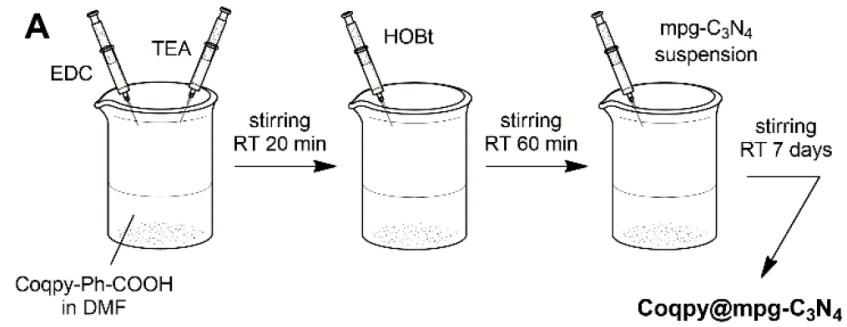

B

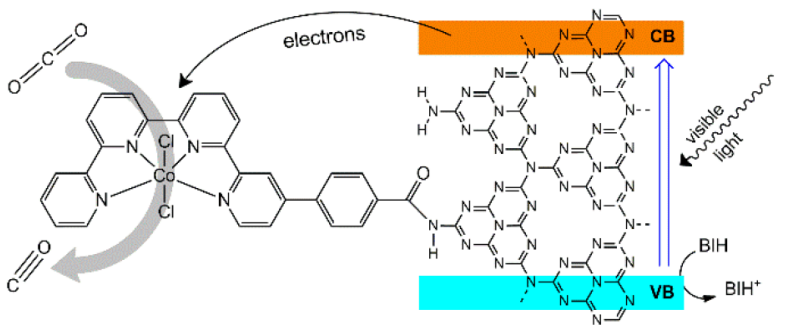

${ }^{a} \mathrm{BIH}$ is the sacrificial electron donor (see text). The Coqpy-Ph$\mathrm{COOH}$ compound is abbreviated Coqpy in all hybrid names.

robust association led to excellent long-term stability upon several days of irradiation, while efficient electron transfer to the cobalt catalyst allowed for efficient and selective $\mathrm{CO}_{2}$ reduction to $\mathrm{CO}$.

\section{RESULTS AND DISCUSSION}

Molecular Materials Hybrid Assemblies Preparation. Mesoporous graphic carbon nitride $\left(\mathrm{mpg}-\mathrm{C}_{3} \mathrm{~N}_{4}\right)^{40}$ and graphitic nanosheets of graphitic carbon nitride $\left(\mathrm{nsg}-\mathrm{C}_{3} \mathrm{~N}_{4}\right)^{32}$ were prepared according to previously reported methods. Coqpy@ mpg- $\mathrm{C}_{3} \mathrm{~N}_{4}$ was prepared (Scheme $1 \mathrm{~A}$ ) by the addition of 1ethyl-3-(3-(dimethylaminopropyl)carbodiimide (EDC, 3.05 $\mathrm{mg}, 16 \mu \mathrm{mol}$ ) and triethylamine (TEA, $2.2 \mu \mathrm{L}, 16 \mu \mathrm{mol})$ to a stirring suspension of Coqpy-Ph-COOH $(4.48 \mathrm{mg}, 8 \mu \mathrm{mol}$; see Figures $\mathrm{S} 1$ and S2 for synthesis and characterization) in DMF $(5 \mathrm{~mL})$. The mixture was stirred for $20 \mathrm{~min}$ at room temperature, and then a 1-hydroxybenzotriazole ( $\mathrm{HOBt}, 2.14$ $\mathrm{mg}, 16 \mu \mathrm{mol}$ ) solution in $0.5 \mathrm{~mL}$ of DMF was added and kept stirring for $1 \mathrm{~h}$. Next, mpg- $\mathrm{C}_{3} \mathrm{~N}_{4}(80 \mathrm{mg})$ suspension in $2 \mathrm{~mL}$ of DMF was introduced into the mixture. After stirring for 7 days, the product was isolated by filtration on a nylon membrane $(0.1 \mu \mathrm{m})$. Excess Coqpy-Ph-COOH and other impurities were removed through washing cycles, including sonication, filtration, and resuspension of the solid in DMF $(200 \mathrm{~mL})$. UV-vis spectroscopy was used to check the filtrate to ensure that no Coqpy- $\mathrm{Ph}-\mathrm{COOH}$ remained in the final washing. After filtration, Coqpy@mpg- $\mathrm{C}_{3} \mathrm{~N}_{4}$ was washed with ultrapure water several times, following the above procedure. Finally, the precipitate was dried under vacuum to yield the Coqpy@mpg- $\mathrm{C}_{3} \mathrm{~N}_{4}$ hybrid. Coqpy@nsg- $\mathrm{C}_{3} \mathrm{~N}_{4}$ was similarly synthesized by using nsg- $\mathrm{C}_{3} \mathrm{~N}_{4}$ instead of mpg- $\mathrm{C}_{3} \mathrm{~N}_{4}$. The adsorbed sample, noted Coqpy-mpg- $\mathrm{C}_{3} \mathrm{~N}_{4}$, was prepared by dissolving Coqpy-Ph-COOH (1 mg) into a mpg- $\mathrm{C}_{3} \mathrm{~N}_{4}(25$ $\mathrm{mg}$ ) suspension in $25 \mathrm{~mL}$ of DMF. After stirring overnight, the final solid was obtained by a similar post-treatment including filtration and washing cycles, but no sonication. In a final step, the precipitate was dried under vacuum to yield the Coqpympg- $\mathrm{C}_{3} \mathrm{~N}_{4}$, for which the Co complex is physically adsorbed onto the carbon nitride material. For the mixed sample, noted Coqpy-Ph-COOH/mpg- $\mathrm{C}_{3} \mathrm{~N}_{4}, \mathrm{mpg}-\mathrm{C}_{3} \mathrm{~N}_{4}$ was dispersed into acetonitrile and sonicated to obtain a uniform suspension. Then a known amount of Coqpy-Ph-COOH solution was added into the suspension, and the photocatalysis experiments started immediately.

Spectroscopic Characterizations. Nitrogen adsorption/ desorption experiment: The pore volume of ca. $0.50 \mathrm{~cm}^{3} \mathrm{~g}^{-1}$ and the specific surface area of $111 \mathrm{~m}^{2} \mathrm{~g}^{-1}$ of synthesized mpg$\mathrm{C}_{3} \mathrm{~N}_{4}$ were measured by a nitrogen adsorption/desorption isothermal test at $77 \mathrm{~K}$. The morphology was maintained through the grafting procedure and after photoreaction, with a final pore volume of $0.522 \mathrm{~cm}^{3} \mathrm{~g}^{-1}$ and a specific surface area of $119 \mathrm{~m}^{2} \mathrm{~g}^{-1}$ (see Figure S3 and Table S1).

Infrared Spectra. IR spectra of $\mathrm{mpg}-\mathrm{C}_{3} \mathrm{~N}_{4}$, Coqpy-Ph$\mathrm{COOH}$, and the hybrid assembly are presented in Figure S4. Typical features of mpg- $\mathrm{C}_{3} \mathrm{~N}_{4}$ can be observed for both bare material and hybrid assembly, including $\mathrm{N}-\mathrm{H}$ stretching in the $3200 \mathrm{~cm}^{-1}$ region with a $-\mathrm{NH}_{2}$ specific stretching around $3280 \mathrm{~cm}^{-1}$, an interchain $\mathrm{NH} \cdots \mathrm{O}-\mathrm{C}$ bonding around 3170 $\mathrm{cm}^{-1}$, triazine features around $810 \mathrm{~cm}^{-1}$, and a broad band spanning the $1100-1600 \mathrm{~cm}^{-1}$ region that can be assigned to in-plane $\mathrm{C}-\mathrm{N}$ stretching and bending vibrations of the graphitic layers. ${ }^{41}$ In the hybrid spectrum, despite weak signals due to low catalyst loading, we still observed characteristic peaks at 1682 and $1558 \mathrm{~cm}^{-1}$ attributed to $\mathrm{C}=\mathrm{O}$ stretching of the amide link and to in-plane $\mathrm{N}-\mathrm{H}$ deformation coupled with $\mathrm{C}-\mathrm{N}$ stretching.

X-ray Photoelectron Spectroscopy (XPS). As shown in Figures S5 and S6 as well as Table S2, typical XPS signatures originating from $\mathrm{C} 1 \mathrm{~s}, \mathrm{~N} 1 \mathrm{~s}$, and $\mathrm{O} 1 \mathrm{~s}$ atoms within the hybrid are observed at binding energies of about 287, 400, and 532 $\mathrm{eV} .^{41}$ The $\mathrm{C} 1 \mathrm{~s}$ spectrum is composed of three components: a major one at $288.9 \mathrm{eV}$ corresponding to $\mathrm{NC}=\mathrm{N}$ (carbon nitride), a second one at $284.9 \mathrm{eV}$ from $\mathrm{C}-\mathrm{C} / \mathrm{C}-\mathrm{H}$, and a 
third one at $286.3 \mathrm{eV}$ from $\mathrm{C}-\mathrm{N}$ attributed to the coupling of $\mathrm{C}_{3} \mathrm{~N}_{4}$ and Coqpy-Ph-COOH units. The $\mathrm{O} 1 \mathrm{~s}$ peak centered at $532.4 \mathrm{eV}$ is attributed to the amide $\mathrm{C}=\mathrm{O}$. The $\mathrm{N} 1 \mathrm{~s}$ peaks centered at 398.8 and $399.9 \mathrm{eV}$ belong to $\mathrm{C}=\mathrm{N}$ and $\mathrm{N}(\mathrm{C})_{3}$ of the triazine motif, respectively. A weak $\mathrm{N}$ 1s peak centered at $404.8 \mathrm{eV}$ is also observed for the nitride substrate. The peak centered at $401.1 \mathrm{eV}$ is consistent with $\mathrm{C}-\mathrm{N}-\mathrm{H}$ from covalent amide linkage. On the other hand, a weak Co $2 \mathrm{p}$ signature at ca. $782 \mathrm{eV}$ can be observed, proving the presence of cobalt inside the hybrid material.

Inductively Coupled Plasma-Optical Emission Spectroscopy (ICP-OES). Amounts of cobalt in the different hybrid materials (covalently linked or adsorbed) are given in Table 1. The equivalent concentration of Coqpy was also

Table 1. Amount of Cobalt in Hybrid Materials Determined by ICP and Equivalent Coqpy Concentration in Solution

\begin{tabular}{lccc}
\multicolumn{1}{c}{ hybrid } & co $(w t \%)$ & Coqpy $\left(\mu \mathrm{mol} \mathrm{g}^{-1}\right)$ & [Coqpy] $^{a}(\mu \mathrm{M})$ \\
\hline Coqpy@mpg-C $\mathrm{C}_{3} \mathrm{~N}_{4}$ & 0.00876 & 1.48 & 3.0 \\
Coqpy-mpg-C $\mathrm{C}_{3} \mathrm{~N}_{4}$ & 0.00744 & 1.26 & 2.5 \\
Coqpy@nsg-C $\mathrm{C}_{3} \mathrm{~N}_{4}$ & 0.02670 & 4.53 & 9.0
\end{tabular}

${ }^{a}$ Calculated for $6 \mathrm{mg}$ of hybrid material suspended in a $3 \mathrm{~mL}$ solution.

calculated and systematically used for TON calculation. From these measurements, it appears that the Coqpy loading is higher when nsg- $\mathrm{C}_{3} \mathrm{~N}_{4}$ is used, most probably thanks to more favorable structural properties. Interestingly, equivalent Coqpy concentration is very similar to typical conditions used in homogeneous catalysis. ${ }^{42,43}$

Cyclic Voltammetry (CV). The CV of Coqpy-Ph-COOH is shown in Figure S7. Under argon and upon reductive scan, a reversible wave at $-0.7 \mathrm{~V}$ vs SCE is observed and is attributed to the $\mathrm{Co}^{\mathrm{II}}-\mathrm{Co}^{\mathrm{I}}$. Further reduction first leads to quasireversible waves at $-1.1 \mathrm{~V}$ vs SCE and $-1.4 \mathrm{~V}$ vs SCE due to combined metal and ligand-based reduction, in line with previous reports. ${ }^{39,44}$ Under a $\mathrm{CO}_{2}$ atmosphere, an increase is observed on the latter wave, showing that Coqpy-Ph- $\mathrm{COOH}$ possesses the ability to catalytically reduce $\mathrm{CO}_{2}$. In the presence of a weak Brönsted acid (phenol), the catalytic current further drastically increases. The onset potential of the catalytic wave is positive to the position of the conduction band $(\mathrm{CB})$ of $\mathrm{mpg}_{-} \mathrm{C}_{3} \mathrm{~N}_{4}$, located at ca. $-1.35 \mathrm{~V}$ vs SCE, as reported elsewhere, ${ }^{1}$ indicating that the illuminated semiconductive material can reduce the cobalt molecular catalyst.

Photoinduced Electron Transfer. Irradiation of mpg$\mathrm{C}_{3} \mathrm{~N}_{4}$ with visible light $(\lambda>400 \mathrm{~nm})$ allows electron-hole separation with the promotion of an electron in the conduction band of the semiconductor. The efficiency of the electron transfer (ET) to Coqpy-Ph-COOH is a key parameter for the catalytic process which can be evaluated by mpg- $\mathrm{C}_{3} \mathrm{~N}_{4}$ emission quenching experiments in the presence of either $\mathrm{BIH}$ or Coqpy-Ph-COOH (Figures S8 and S9). The steadystate emission spectrum of suspended mpg- $\mathrm{C}_{3} \mathrm{~N}_{4}$ in acetonitrile shows two peaks of similar intensity at ca. 490 and 540 $\mathrm{nm}$, in accordance with previous studies. ${ }^{45}$ In the presence of $\mathrm{BIH}$ or Coqpy-Ph-COOH, we observe a moderate but linear emission decay with quencher concentration. Electron transfer rate constant determination through Stern-Volmer $(\mathrm{S}-\mathrm{V})$ analysis requires the excited-state lifetime of mpg- $\mathrm{C}_{3} \mathrm{~N}_{4}$. Several studies reported a very short lifetime for $\mathrm{C}_{3} \mathrm{~N}_{4}$ excited states. ${ }^{4,46,47}$ In another recent paper the excited states and electron transfer dynamics of g- and mpg- $\mathrm{C}_{3} \mathrm{~N}_{4}$ hybridized with a $\mathrm{Ru}$ mononuclear complex were investigated. ${ }^{45}$ It was shown that the emissive excited states of mpg- $\mathrm{C}_{3} \mathrm{~N}_{4}$ decayed with a three-component (from 0.7 to $12 \mathrm{~ns}$ ) kinetics, but these excited states were not quenched neither by a hole scavenger nor by an electron acceptor. It was further concluded that emissive excited states are mainly located in the bulk region of the carbon nitride and thus insensitive to the presence of quencher, whereas less to nonemissive excited states were mainly surface states responsible for ultrafast electron transfer (a few picoseconds).

In our measurements, we observed that the two emission peaks were quenched at different rates both with $\mathrm{BIH}$ and Coqpy-Ph-COOH, which could be explained if these peaks correspond to slightly different excited states. However, the Stern-Volmer constant (Table S3) is much larger (by a factor >3900) in the case of the cobalt complex and largely counterbalances the smaller concentration of the catalyst as compared to the sacrificial donor (by a factor ca. 16) in the photocatalytic experiments. In the photocatalytic process, mpg$\mathrm{C}_{3} \mathrm{~N}_{4}$ is thus oxidized. Electron transfer is efficient and most probably proceeds from mpg- $\mathrm{C}_{3} \mathrm{~N}_{4}$ to the cobalt(II) catalyst, with $\mathrm{BIH}$ sacrificially transferring electrons back to the material, even if we could not determine the exact rate constant. It must be noted that we cannot probe the second electron transfer to the as generated $\mathrm{Co}(\mathrm{I})$ species, but we assume that the process is similar to the first one. We also measured the photocurrent response of mpg- $\mathrm{C}_{3} \mathrm{~N}_{4}$, Coqpy/ mpg- $\mathrm{C}_{3} \mathrm{~N}_{4}$ (obtained by simple mixing of Coqpy-Ph- $\mathrm{COOH}$, and mpg- $\mathrm{C}_{3} \mathrm{~N}_{4}$ as previously explained) and Coqpy@mpg$\mathrm{C}_{3} \mathrm{~N}_{4}$ (Figure 1). The materials were deposited at a FTO

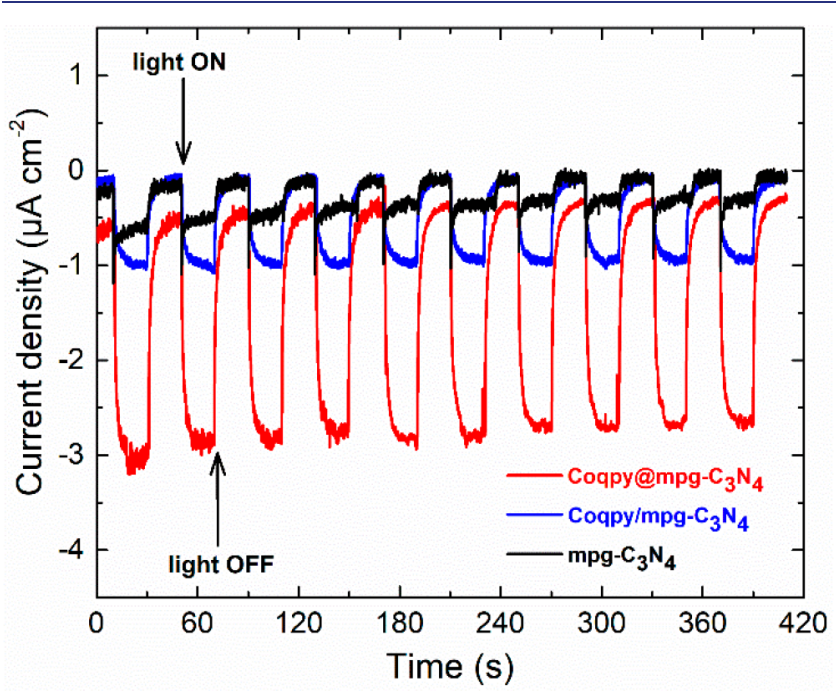

Figure 1. Transient (light on/off) photocurrent responses of mpg$\mathrm{C}_{3} \mathrm{~N}_{4}$ (black), Coqpy/mpg- $\mathrm{C}_{3} \mathrm{~N}_{4}$ (blue), and Coqpy@mpg- $\mathrm{C}_{3} \mathrm{~N}_{4}$ (red) hybrid ink dropped onto a FTO electrode connected to a platinum electrode (no bias, $0.1 \mathrm{M} \mathrm{Na}_{2} \mathrm{SO}_{4}$ solution).

electrode which was connected to a platinum electrode in a 0.1 $\mathrm{M} \mathrm{Na} \mathrm{SO}_{4}$ solution without any bias (see the Experimental Section for details). The current responses upon light illumination of mpg- $\mathrm{C}_{3} \mathrm{~N}_{4}$ and Coqpy/mpg- $\mathrm{C}_{3} \mathrm{~N}_{4}$ were negligible, whereas the covalently linked Coqpy@mpg- $\mathrm{C}_{3} \mathrm{~N}_{4}$ assembly showed a large, quickly rising, and stable current response, only with a slight attenuation being visible after ten cycles. This confirms that the covalent link between the two 
moieties greatly enhanced electronic communication, as expected.

Upon running 10 consecutive illumination cycles, it was also observed that the current response was maintained with no significant attenuation or time delay. The electronic impedance spectroscopy (EIS) responses of $\mathrm{mpg}-\mathrm{C}_{3} \mathrm{~N}_{4}$, Coqpy/mpg$\mathrm{C}_{3} \mathrm{~N}_{4}$, and Coqpy@mpg- $\mathrm{C}_{3} \mathrm{~N}_{4}$ were further measured (Figure 2), showing that the charge-transfer resistance of Coqpy@

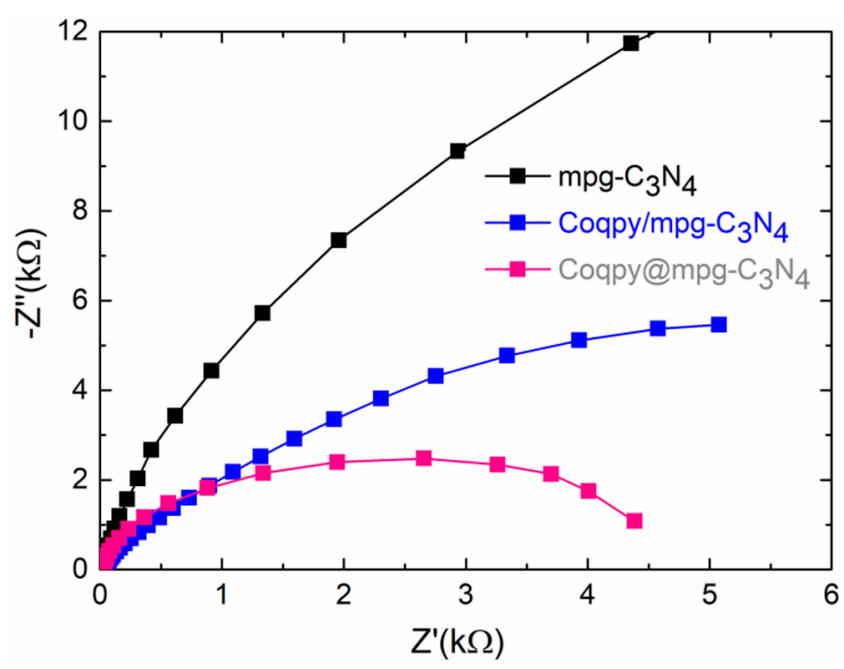

Figure 2. EIS (electrochemical impedance spectroscopy) responses of mpg- $\mathrm{C}_{3} \mathrm{~N}_{4}$ (black), Coqpy/mpg- $\mathrm{C}_{3} \mathrm{~N}_{4}$ (blue), and Coqpy@mpg$\mathrm{C}_{3} \mathrm{~N}_{4}$ (pink) hybrid ink dropped onto a FTO electrode in the dark (0.1 $\mathrm{M} \mathrm{Na}_{2} \mathrm{SO}_{4}$ solution).

mpg- $\mathrm{C}_{3} \mathrm{~N}_{4}$ is smaller than Coqpy/mpg- $\mathrm{C}_{3} \mathrm{~N}_{4}$ and mpg- $\mathrm{C}_{3} \mathrm{~N}_{4}$. The hybrid Coqpy@mpg- $\mathrm{C}_{3} \mathrm{~N}_{4}$ thus possesses the lowest impedance, illustrating that the covalent linking significantly enhances conductivity of the material.

Visible-Light-Driven $\mathrm{CO}_{2}$ Reduction Catalysis. As shown in Figure 3, visible light illumination of the catalyst suspension furnishes CO with very high selectivity (97\%) and long-term durability since the catalytic material can evolve the

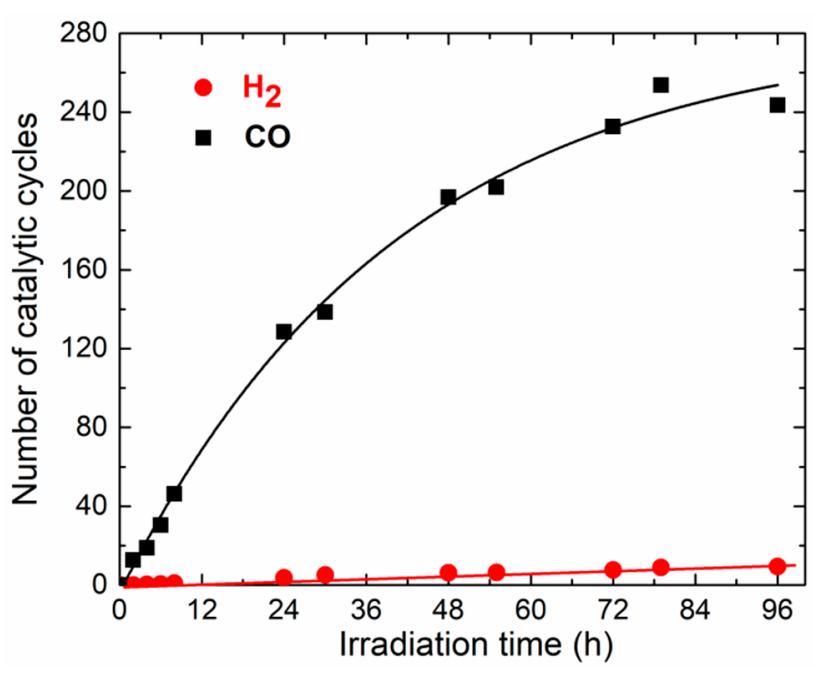

Figure 3. Generation of $\mathrm{CO}$ (black squares) and $\mathrm{H}_{2}$ (red circles) over 4 days upon visible-light irradiation $(\lambda>400 \mathrm{~nm})$ of a $\mathrm{CO}_{2}$-saturated ACN solution containing $6 \mathrm{mg}$ of Coqpy@mpg- $\mathrm{C}_{3} \mathrm{~N}_{4}, 0.05 \mathrm{M} \mathrm{BIH}$ (sacrificial donor), and $0.03 \mathrm{M} \mathrm{PhOH}$ (proton source). gas product over a period of about 4 days, reaching a TON for $\mathrm{CO}$ of 254 . The origin of carbon was asserted by running isotope-labeled experiments with ${ }^{13} \mathrm{CO}_{2}$ giving ${ }^{13} \mathrm{CO}$ as the product (see MS spectrum, Figure S10). Table 2 reports data

Table 2. Visible-Light-Driven $\mathrm{CO}_{2}$ Reduction with Coqpy Catalyst Covalently Attached to $\mathrm{Mpg}-\mathrm{C}_{3} \mathrm{~N}_{4}$

\begin{tabular}{|c|c|c|c|c|c|}
\hline \multirow[b]{2}{*}{ entry } & \multirow[b]{2}{*}{ catalyst $^{a}$} & \multicolumn{2}{|c|}{ product $(\mu \mathrm{mol})$} & \multirow[b]{2}{*}{$\mathrm{TON}_{\mathrm{CO}}{ }^{b}$} & \multirow{2}{*}{$\begin{array}{c}\mathrm{CO} \\
\text { selectivity } \\
(\%)\end{array}$} \\
\hline & & $\mathrm{H}_{2}$ & $\mathrm{CO}$ & & \\
\hline 1 & Coqpy@mpg- $\mathrm{C}_{3} \mathrm{~N}_{4}$ & 0.06 & 1.15 & 128 & 98 \\
\hline 2 & $\begin{array}{l}\text { Coqpy-Ph-COOH/ } \\
\text { mpg-C }{ }_{3} \mathrm{~N}_{4}\end{array}$ & 0.04 & 0.31 & 37 & 88 \\
\hline 3 & Coqpy-mpg- $\mathrm{C}_{3} \mathrm{~N}_{4}$ & 0.03 & 0.15 & 21 & 83 \\
\hline 4 & Coqpy@mpg- $\mathrm{C}_{3} \mathrm{~N}_{4}{ }^{c}$ & 0.013 & 0 & 0 & 0 \\
\hline 5 & Coqpy@mpg- $\mathrm{C}_{3} \mathrm{~N}_{4}{ }^{d}$ & 0.001 & 0 & 0 & 0 \\
\hline 6 & mpg- $\mathrm{C}_{3} \mathrm{~N}_{4}$ & 0.012 & 0.017 & & 59 \\
\hline 7 & Coqpy $/ \mathrm{Al}_{2} \mathrm{O}_{3}$ & 0.004 & 0.062 & 8 & 94 \\
\hline 8 & $\mathrm{CoCl}_{2} / \mathrm{mpg}_{-} \mathrm{C}_{3} \mathrm{~N}_{4}$ & 0.013 & 0.018 & 1.7 & 58 \\
\hline 9 & Coqpy@nsg- $\mathrm{C}_{3} \mathrm{~N}_{4}$ & 0.018 & 0.81 & 27 & 98 \\
\hline 10 & Coqpy/mpg- $\mathrm{C}_{3} \mathrm{~N}_{4}$ & 0.035 & 0.22 & 26 & 86 \\
\hline 11 & Coqpy-mpg- $\mathrm{C}_{3} \mathrm{~N}_{4}$ & 0.09 & 0.52 & 58 & 85 \\
\hline
\end{tabular}

${ }^{a}$ Reaction conditions: $6 \mathrm{mg}$ of catalyst $\left(3 \mu \mathrm{M}\right.$ Coqpy) in a $\mathrm{CO}_{2}$ saturated ACN solution containing $0.05 \mathrm{M} \mathrm{BIH}$ and $0.03 \mathrm{M} \mathrm{PhOH}$. A $6 \mathrm{~mL}$ quartz cell with a septum was used as the reaction vessel, and an AM1.5G solar simulator equipped with a $400 \mathrm{~nm}$ long-pass filter was used as irradiation source. Reaction time: $24 \mathrm{~h}$. Amount of Coqpy in catalyst: covalently linked at mpg- $\mathrm{C}_{3} \mathrm{~N}_{4}$ (Coqpy@mpg- $\mathrm{C}_{3} \mathrm{~N}_{4}$ ), $3 \mu \mathrm{M}$; mixed with carbon nitride (Coqpy/mpg- $\mathrm{C}_{3} \mathrm{~N}_{4}$ ), $3 \mu \mathrm{M}$; adsorbed at the carbon nitride surface (Coqpy-mpg- $\mathrm{C}_{3} \mathrm{~N}_{4}$ ), $2.5 \mu \mathrm{M}$; mixed with $\mathrm{Al}_{2} \mathrm{O}_{3}$ (Coqpy $/ \mathrm{Al}_{2} \mathrm{O}_{3}$ ), $3 \mu \mathrm{M}$; covalently linked at nsg- $\mathrm{C}_{3} \mathrm{~N}_{4}$ (Coqpy@nsg- $\mathrm{C}_{3} \mathrm{~N}_{4}$ ), $9 \mu \mathrm{M}$. ${ }^{b}$ Relative to the amount of Coqpy or $\mathrm{CoCl}_{2} .{ }^{c}$ Under an argon atmosphere. ${ }^{d}$ In the dark (results obtained with a $\mathrm{Hg}$ lamp as irradiation source are given in Table S4).

obtained after $24 \mathrm{~h}$ irradiation. $\mathrm{TON}_{\mathrm{CO}}$ of 128 can be converted to $8 \mu \mathrm{mol} \mathrm{g}^{-1} \mathrm{~h}^{-1}$ to facilitate comparison with other catalytic systems. No formate was identified from the liquid phase. Complete blank experiments are also given in Table 2, showing that all components of the catalytic system are needed. Experiments performed with cobalt chloride salt mixed with carbon nitride or Coqpy mixed $\mathrm{Al}_{2} \mathrm{O}_{3}$ suspension only furnishes a very low amount of reduction products (entries 7 and 8 , respectively, Table 2). Moreover, simple mixing of the cobalt molecular complex with mpg- $\mathrm{C}_{3} \mathrm{~N}_{4}$ considerably decreases the amount of $\mathrm{CO}$ produced (entries 2 and 3, Table 2), and concomitantly the selectivity for $\mathrm{CO}_{2}$ reduction significantly diminishes.

These observations clearly indicate that covalent grafting of the molecular catalyst enhances catalysis. Recently, polymerized cobalt phthalocyanine mixed with mesoporous carbon nitride was shown to evolve $\mathrm{CO}$ with ca. 90 TON and a selectivity in the range of $80 \% .{ }^{14}$ In another approach, $\mathrm{Co}^{2+}$ single sites embedded into $\mathrm{C}_{3} \mathrm{~N}_{4}$ material led to $\mathrm{CO}$ production with a selectivity inferior to $80 \%$ and ca. 200 $\mathrm{TON}^{48}$ In the former case, large loading will block incoming light to reach the semiconductive material while in the latter case it will drive to the formation of $\mathrm{CoO}$, leading to decrease photocatalytic activity in both cases. The covalent attachment of an efficient and selective molecular catalyst to the polymeric material thus appears as a promising approach to catalyze $\mathrm{CO}_{2}$ reduction, allowing for better control of the catalyst structure 
on one hand and better selectivity and activity on the other hand.

To further investigate the stability of the hybrid assembly, we re-employed the same hybrid for four successive cycles. Each cycle corresponded to $24 \mathrm{~h}$ visible-light irradiation of a standard Coqpy@mpg- $\mathrm{C}_{3} \mathrm{~N}_{4} / \mathrm{BIH} / \mathrm{PhOH}$ ACN solution. After each cycle, the hybrid was washed with $\mathrm{ACN}$ with sonication and then centrifuged. After drying, the hybrid was dispersed again into a fresh ACN containing $\mathrm{BIH}$ and $\mathrm{PhOH}$ and then saturated with $\mathrm{CO}_{2}$ for $30 \mathrm{~min}$ to start a new photocatalytic cycle. Results (Figure 4) show a remarkable stability of $\mathrm{CO}$

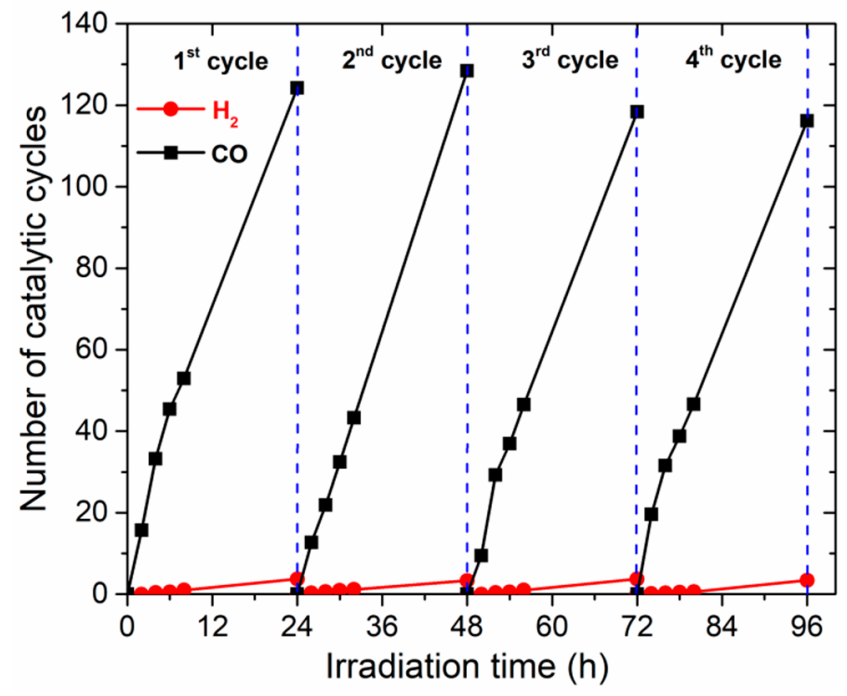

Figure 4. Generation of $\mathrm{CO}$ (black squares) and $\mathrm{H}_{2}$ (red circles) during four consecutive $24 \mathrm{~h}$ irradiation cycles using the same hybrid material (see text).

production in each cycle, asserting the absence of hybrid degradation during irradiation. It also illustrates the ability to easily recycle the hybrid material for further use. A total number of ca. 500 catalytic cycles was reached after $96 \mathrm{~h}$. Taking into account that $\mathrm{CO}_{2}$-to- $\mathrm{CO}$ conversion necessitates two electrons, the apparent quantum yield for $\mathrm{CO}$ formation is $\Phi=0.25 \%$ (see the Supporting Information).

X-ray diffraction spectra of mpg- $\mathrm{C}_{3} \mathrm{~N}_{4}$, nsg- $\mathrm{C}_{3} \mathrm{~N}_{4}$, Coqpy-Ph$\mathrm{COOH}$, and Coqpy@mpg- $\mathrm{C}_{3} \mathrm{~N}_{4}$ before and after irradiation are shown in Figure S12. Coqpy@mpg- $\mathrm{C}_{3} \mathrm{~N}_{4}$ spectra before and after irradiation show mixed diffraction peaks including characteristic ones of the complex at $7.1^{\circ}, 10.1^{\circ}, 12.5^{\circ}, 16.1^{\circ}$, $21.6^{\circ}, 23.9^{\circ}, 27.3^{\circ}$, and $29.9^{\circ}$ as well as the peak of $\mathrm{C}_{3} \mathrm{~N}_{4}$ at $27.5^{\circ}$. The strong diffraction peak due to the stacking of conjugated aromatic rings that can be assigned to the (002) plane of the heptazine-based $\mathrm{g}-\mathrm{C}_{3} \mathrm{~N}_{4}$. In addition, the comparison of hybrids patterns with one typical porous material, namely an aluminum silicate zeolite (JCPDS card 00-023-0214), shows common features. In addition, no characteristic diffraction peaks corresponding to cobalt oxide were observed. XPS data in Figure S6 also confirmed the presence of cobalt in Coqpy@mpg- $\mathrm{C}_{3} \mathrm{~N}_{4}$ before and after photocatalysis as well as in the adsorbed Coqpy-mpg- $\mathrm{C}_{3} \mathrm{~N}_{4}$. Absorption spectra of $\mathrm{PhOH}, \mathrm{BIH}$, qpy-Ph-COOH ligand, and Coqpy-Ph-COOH complex as well as photochemical mixture before and after irradiation are shown in Figure S13. The UVvis absorption spectrum conserves the same spectral trends compared to before irradiation, albeit with a lower intensity.
No characteristic absorption peak of the ligand could be observed. All these results further support stability of the catalytic material upon long time irradiation.

\section{CONCLUSION}

The hybrid Coqpy@mpg- $\mathrm{C}_{3} \mathrm{~N}_{4}$ material is among the first examples comprising a molecular catalyst covalently anchored to carbon nitride for $\mathrm{CO}_{2} \mathrm{RR}$ and only containing abundant elements. Among such rare examples, Coqpy@mpg- $\mathrm{C}_{3} \mathrm{~N}_{4}$ is highly selective and active toward $\mathrm{CO}$ production, showing in addition long-term stability. It thus combines the selectivity of molecular catalysts to the excellent stability of solid materials. The possibility to independently tune the structure of the metal complex and the structure of the semiconductive material (band gap and conduction band energy modulation) along with the ability to modulate the electronic interaction between the two components opens a new pathway for developing and optimizing highly active catalytic materials for the visible-light-driven reduction of $\mathrm{CO}_{2}$.

\section{EXPERIMENTAL SECTION}

Chemicals. Cobalt(II) chloride hexahydrate (Acros Organics, 98\%), 4-methoxycarbonylphenylboronic acid (J\&K, 98\%), $\mathrm{Pd}\left(\mathrm{PPh}_{3}\right)_{4}$ (J\&K, 98\%), 1-hydroxybenzotriazole hydrate (HOBt, Sigma-Aldrich, 97\%), $N$-(3-(dimethylaminopropyl)- $N^{\prime}$-ethylcarbodiimide hydrochloride (EDC, Sigma-Aldrich, >99\%), N,N-dimethylformamide (DMF, Acros Organics, 99.8\%), triethylamine (TEA, Acros Organics, 99\%), phenol (PhOH, Fluka, Ultra >99.5\%), and acetonitrile (ACN, Acros Organics, 99.8\%) were used as received. Ultrapure water was obtained from a TKA MicroPure system. Argon (>99.998\%) and ${ }^{12} \mathrm{CO}_{2}(>99.7 \%)$ were from Air Liquide, whereas ${ }^{13} \mathrm{CO}_{2}$ (99\% content in atom $\left.{ }^{13} \mathrm{C}\right)$ was from Aldrich. The filter membrane $(0.1 \mu \mathrm{m}$ pore size, $47 \mathrm{~mm}$ diameter, hydrophilic membrane) was purchased from Millipore.

Synthesis. 1,3-Dimethyl-2-phenyl-2,3-dihydro- $1 H$-benzo $[d]$ -

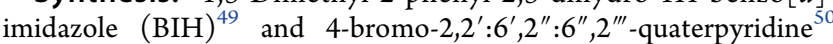
were prepared according to the literature. For the synthesis of 4$\left(\left[2,2^{\prime}: 6^{\prime}, 2^{\prime \prime}: 6^{\prime \prime}, 2^{\prime \prime \prime}\right.\right.$-quaterpyridin]-4-yl)benzoic acid (qpy-Ph-COOH),

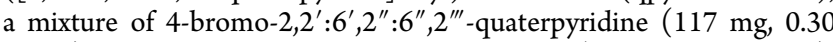
$\mathrm{mmol})$, 4-methoxycarbonylphenylboronic acid $(63 \mathrm{mg}, 0.35 \mathrm{mmol})$, $\mathrm{Pd}\left(\mathrm{PPh}_{3}\right)_{4}(17.3 \mathrm{mg}, 0.015 \mathrm{mmol})$, and $\mathrm{Na}_{2} \mathrm{CO}_{3}(159 \mathrm{mg}, 1.5 \mathrm{mmol})$ in $\mathrm{MeOH} / \mathrm{H}_{2} \mathrm{O}(10 \mathrm{~mL}, 10: 1)$ was refluxed for $24 \mathrm{~h}$ under argon. After evaporation of the solvent, the residue was washed with water and isopropanol to give crude methyl $4-\left(\left[2,2^{\prime}: 6^{\prime}, 2^{\prime \prime}: 6^{\prime \prime}, 2^{\prime \prime \prime}\right.\right.$-quaterpyridin]-4-yl)benzoate, which was used without further purification. To the crude methyl $4-\left(\left[2,2^{\prime}: 6^{\prime}, 2^{\prime \prime}: 6^{\prime \prime}, 2^{\prime \prime \prime}\right.\right.$-quaterpyridin]-4-yl)benzoate in $\mathrm{THF} / \mathrm{MeOH} / \mathrm{H}_{2} \mathrm{O}(6 \mathrm{~mL}, 4: 1: 1)$ was added $\mathrm{LiOH}(3.0 \mathrm{mmol}, 127$ $\mathrm{mg}$ ), and then the mixture was refluxed for $12 \mathrm{~h}$. After cooling, the mixture was filtered and acidified with $1 \mathrm{M} \mathrm{HCl}$. Upon removing organic solvent, a white product (qpy-Ph-COOH) was precipitated out. The solid was filtered and washed with water. After drying under vacuum for $12 \mathrm{~h}$, qpy-Ph-COOH was obtained as a white solid (Figure S1). Yield: $87 \mathrm{mg}(67 \%) .{ }^{1} \mathrm{H}$ NMR $\left(400 \mathrm{MHz}, \mathrm{DMSO}-d_{6}\right): \delta$ $8.98(\mathrm{~s}, 1 \mathrm{H}), 8.92-8.88(\mathrm{~m}, 3 \mathrm{H}), 8.85\left(\mathrm{~d},{ }^{3} \mathrm{~J}_{(\mathrm{H}, \mathrm{H})}=4.0 \mathrm{~Hz}, 1 \mathrm{H}\right), 8.76$ $\left(\mathrm{d},{ }^{3} J_{(\mathrm{H}, \mathrm{H})}=8.0 \mathrm{~Hz}, 1 \mathrm{H}\right), 8.63\left(\mathrm{~d},{ }^{3} J_{(\mathrm{H}, \mathrm{H})}=8.0 \mathrm{~Hz}, 1 \mathrm{H}\right), 8.55(\mathrm{~d}$, $\left.{ }^{3} J_{(\mathrm{H}, \mathrm{H})}=8.0 \mathrm{~Hz}, 1 \mathrm{H}\right), 8.28-8.22(\mathrm{~m}, 3 \mathrm{H}), 8.17-8.12(\mathrm{~m}, 4 \mathrm{H}), 8.03$ $\left(\mathrm{d},{ }^{3} J_{(\mathrm{H}, \mathrm{H})}=4.0 \mathrm{~Hz}, 1 \mathrm{H}\right), 7.70\left(\mathrm{t},{ }^{3} J_{(\mathrm{H}, \mathrm{H})}=8.0,1 \mathrm{H}\right)$.

For the synthesis of Coqpy-Ph- $\mathrm{COOH}$, a mixture of qpy-Ph$\mathrm{COOH}(43 \mathrm{mg}, 0.1 \mathrm{mmol})$ and $\mathrm{CoCl}_{2} \cdot 6 \mathrm{H}_{2} \mathrm{O}(36 \mathrm{mg}, 0.15 \mathrm{mmol})$ in $\mathrm{CH}_{3} \mathrm{OH}(20 \mathrm{~mL})$ was stirred at room temperature for $24 \mathrm{~h}$. After evaporation of solvent, the residue was washed with water and isopropanol to give Coqpy- $\mathrm{Ph}-\mathrm{COOHCl} 2 \cdot 2.5 \mathrm{H}_{2} \mathrm{O}$ as a pale yellow solid (Figure S1). Yield: $50 \mathrm{mg}$ (83\%). Coqpy-Ph-COOHCl 2 . 2.5 $\mathrm{H}_{2} \mathrm{O}$ : Anal. Calcd (Found) for $\mathrm{C}_{27} \mathrm{H}_{18} \mathrm{Cl}_{2} \mathrm{CoN}_{4} \mathrm{O}_{2} \cdot 2.5 \mathrm{H}_{2} \mathrm{O}$ : Co, 9.37 (9.74), C, 53.57 (53.68), H, 3.83 (3.66), N, 9.26 (9.15). ESI-MS in $\mathrm{MeOH}$ (Figure S2): $m / z$ 244.7, [Coqpy-Ph-COOH] ${ }^{2+}$; 524.0, $[\text { Coqpy-Ph- } \mathrm{COOH} \mathrm{Cl}]^{+}$. 
Physical Characterization. UV-vis absorption spectra were measured with a Cary 60 spectrophotometer (Agilent Tech.). Emission quenching measurements were conducted with a Cary Eclipse fluorescence spectrophotometer (Agilent Tech.), with the excitation wavelength set at $400 \mathrm{~nm}$. Emission intensities used for the Stern-Volmer analysis were taken at 488 and $543 \mathrm{~nm}$, i.e., the emission maximum of mesoporous graphitic carbon nitride. Infrared spectra of Coqpy, $\mathrm{C}_{3} \mathrm{~N}_{4}$, and Coqpy@ $\mathrm{C}_{3} \mathrm{~N}_{4}$ hybrid were measured in reflection mode by using a Spectrum BX FTIR spectrometer (PerkinElmer) equipped with a microscope with an MIR light source and $\mathrm{LiTaO}_{3}$ detector. Spectra were averaged over eight scans with a resolution of $4 \mathrm{~cm}^{-1}$ and were normalized to the background signal. Samples were carefully dried under vacuum (overnight) prior to measurement. The composition (contents in oxygen, nitrogen, carbon, and cobalt elements) of Coqpy@mpg- $\mathrm{C}_{3} \mathrm{~N}_{4}$ samples were determined by X-ray photoelectron spectroscopy (XPS) recorded on an ESCALAB 250 spectrometer (Thermo Sci.) accompanied by a microfocalized X-ray source $(\mathrm{K} \alpha \mathrm{Al} 1486.6 \mathrm{eV})$ and a double monochromator. The BET surface area and pore size distribution measurement were determined by BELSORP-Max (MicrotracBEL Corp., Japan). Inductively coupled plasma-optical emission spectroscopy (ICP-OES) was obtained with an iCAP 6300 ICP-OES CID spectrometer (Thermo Sci.) to determine the concentration in Co in the different hybrid materials. A test was performed with a RACHID detector including a diode array, a peristaltic pump, and argon plasma (analyzes present at $50 \mathrm{rpm}, 1150 \mathrm{~W}$ ).

Electrochemical and Photoelectrochemical Measurements. For photocurrent measurements, $2 \mathrm{mg}$ of each solid material was suspended into $250 \mu \mathrm{L}$ of DMF. The obtained catalytic ink was then dropped on one face of a fluorine-doped tin oxide (FTO) glass electrode $\left(150 \mu \mathrm{L}\right.$ for a $\left.1 \mathrm{~cm}^{2}\right)$ and allowed to dry under ambient conditions prior to use it as the working electrode. The Coqpy/mpg$\mathrm{C}_{3} \mathrm{~N}_{4}$ sample was prepared by grinding mpg- $\mathrm{C}_{3} \mathrm{~N}_{4}$ with Coqpy-Ph$\mathrm{COOH}$. All electro- and photoelectrochemical experiments were performed in a glass cell with a quartz window in $0.1 \mathrm{M} \mathrm{Na}_{2} \mathrm{SO}_{4}$ electrolyte by using a conventional three-electrode system with a platinum wire as a counter electrode and a saturated calomel electrode (SCE) as reference $(-0.241 \mathrm{~V}$ vs NHE). Light illumination was provided by a $300 \mathrm{~W}$ xenon lamp (Oriel Inst.). The amperometric photocurrent was measured for each switch on/off event by using an Autolab PGSTAT $128 \mathrm{~N}$ potentiostat (Metrohm) with no bias voltage under the UV-vis light irradiation with light chopping every $20 \mathrm{~s}$. Electrochemical impedance spectroscopy (EIS) plots were measured by using a PARSTAT 4000 potentiostat (Princeton Applied Res.) at the corresponding open circuit potential over the frequency ranging from 0.1 to $10^{6} \mathrm{~Hz}$ in the dark.

Photocatalytic Experiments. Photocatalysis, durability, and recycling tests were conducted in a quartz cell with an inner volume of $6 \mathrm{~mL}$. Coqpy@mpg- $\mathrm{C}_{3} \mathrm{~N}_{4}$ hybrid material (6 mg) was dispersed into an ACN solution $(3 \mathrm{~mL})$ containing $\mathrm{BIH}(0.05 \mathrm{M})$ as an electron donor and $\mathrm{PhOH}(0.03 \mathrm{M})$ as a proton source. The suspension was poured to the test cell and then sealed with a rubber septum. After bubbling $\mathrm{CO}_{2}$ for ca. $30 \mathrm{~min}$, the suspension was irradiated with an AM1.5G solar simulator equipped with a $100 \mathrm{~W}$ xenon lamp and a $400 \mathrm{~nm}$ long-pass optical filter. The temperature was controlled during each experiment by a water bath at $298 \mathrm{~K}$. Control experiments (with no catalyst, no $\mathrm{CO}_{2}$, or no light) and comparison experiments (using either Coqpy/mpg- $\mathrm{C}_{3} \mathrm{~N}_{4}$, Coqpy-mpg- $\mathrm{C}_{3} \mathrm{~N}_{4}$, Coqpy $/ \mathrm{Al}_{2} \mathrm{O}_{3}$, Coqpy@nsg- $\mathrm{C}_{3} \mathrm{~N}_{4}$, or $\mathrm{CoCl}_{2}$ ) were conducted in the same conditions as the full system.

Sample Preparation for ICP-OES Analysis. Heterogeneous samples were preprocessed by acid digestion with concentrated nitric acid. In the present case, $2.0 \mathrm{mg}$ of solid sample was introduced into $1.0 \mathrm{~mL}$ of concentrated nitric acid and heated on a hot plate. After cooling to room temperature, the reaction solution was filtered. Then the filtrate was diluted into a $10.0 \mathrm{~mL}$ volumetric flask of ultrapure water for testing.

Reduction Products Analysis. Gaseous reduction products in the sample headspace were analyzed by gas chromatography (GC) equipped with an activated carbon column and a thermal conductivity detector (TCD, GL Sciences, GC323), with argon as the carrier gas. Calibration curves for $\mathrm{H}_{2}$ and $\mathrm{CO}$ were established individually by filling pure gases to a tube with a graduated gastight syringe (Hamilton). ${ }^{13} \mathrm{C}$-labeled experiments were conducted following the same procedure but were also analyzed by a gas chromatograph mass spectrometer (GCMS-QP 2020, Shimadzu). Ionic chromatography (Dionex ICS-1100 ion chromatography system, Thermo Scientific) was employed to check the liquid reduction products in the solution.

Turnover Number (TON) Calculation. TON is defined as the maximum number of catalytic cycles reached until the system stopped reducing $\mathrm{CO}_{2}$. Mole numbers of $\mathrm{H}_{2}$ and $\mathrm{CO}$ were obtained from the conversion of GC peak areas into moles in the sample headspace thanks to calibration curves. Data points are the result of at least two individual experiments, and the relative error on TONs is ca. $5 \%$, corresponding to the size of the data points. TON was based on the mole amount of Coqpy in hybrid Coqpy@ $\mathrm{C}_{3} \mathrm{~N}_{4}$.

\section{ASSOCIATED CONTENT}

UV-vis and infrared spectra, absorption, XPS, XRD, cyclic voltammetry, GC, GC-MS, emission quenching, SEM images and supplemental references (Tables S1S3, Figures S1-S11) (PDF)

\section{AUTHOR INFORMATION}

\section{Corresponding Authors}

Marc Robert - Laboratoire d'Electrochimie Moleculaire, CNRS, Universite de Paris, F-75013 Paris, France; 이이. orcid.org/00000001-7042-4106; Email: robert@u-paris.fr

Gui Chen - School of Environment and Civil Engineering, Dongguan University of Technology, Dongguan, Guangdong, P. R. China; 이이.org/0000-0003-4493-7551;

Email: chengui@dgut.edu.cn

Osamu Ishitani - Department of Chemistry, School of Science, Tokyo Institute of Technology, Tokyo 152-8550, Japan; ○ orcid.org/0000-0001-9557-7854; Email: ishitani@ chem.titech.ac.jp

Tai-Chu Lau - Department of Chemistry, City University of Hong Kong, Kowloon, Hong Kong, P. R. China; ○ orcid.org/ 0000-0002-0867-9746; Email: bhtclau@cityu.edu.hk

\section{Authors}

Bing Ma - Laboratoire d'Electrochimie Moleculaire, CNRS, Université de Paris, F-75013 Paris, France; 이이. orcid.org/00000003-1226-3281

Claire Fave - Laboratoire d'Electrochimie Moleculaire, CNRS, Université de Paris, F-75013 Paris, France; 이이. ord.org/00000001-8146-8702

Lingjing Chen - School of Environment and Civil Engineering, Dongguan University of Technology, Dongguan, Guangdong, P. R. China; orcid.org/0000-0003-3968-1598

Ryo Kuriki - Department of Chemistry, School of Science, Tokyo Institute of Technology, Tokyo 152-8550, Japan; 이이.org/ 0000-0002-3843-2867

Kazuhiko Maeda - Department of Chemistry, School of Science, Tokyo Institute of Technology, Tokyo 152-8550, Japan; (i) orcid.org/0000-0001-7245-8318

Julien Bonin - Laboratoire d'Electrochimie Moleculaire, CNRS, Université de Paris, F-75013 Paris, France; 이이.org/00000001-9943-0219

Complete contact information is available at:

https://pubs.acs.org/10.1021/jacs.9b13930 


\section{Funding}

G.C. acknowledges financial support from a NSFC (21975043) and Guangdong Provincial Key Platforms and Major Scientific Research Projects for Colleges and Universities (2018KTSCX227). T.-C.L. acknowledges financial support from a NSFC/RGC joint research scheme (N_CityU115/18). O.I. and K.M. thank JST CREST (Grant JPMJCR13L1) and JSPS KAKENHI (JP17H06440, JP16H06130, and JP16H06441) for support.

\section{Notes}

The authors declare no competing financial interest.

\section{ACKNOWLEDGMENTS}

B.M. thanks the China Scholarship Council for her $\mathrm{PhD}$ fellowship (CSC student number 201707040042). Partial financial support to M.R. from the Institut Universitaire de France (IUF) is gratefully acknowledged. The authors thank Philippe Decorse for XPS measurements, Sophie Nowak for XRD measurements, and Prof. Jean-Yves Piquemal for nitrogen absorption/desorption tests.

\section{ABBREVIATIONS}

g- $\mathrm{C}_{3} \mathrm{~N}_{4}$, graphitic carbon nitride; mpg- $\mathrm{C}_{3} \mathrm{~N}_{4}$, mesoporous graphitic carbon nitride; nsg- $\mathrm{C}_{3} \mathrm{~N}_{4}$, nanosheet of graphitic carbon nitride; ACN, acetonitrile; DMF, $N, N$-dimethylformamide.

\section{REFERENCES}

(1) Wang, X.; Blechert, S.; Antonietti, M. Polymeric Graphitic Carbon Nitride for Heterogeneous Photocatalysis. ACS Catal. 2012, 2 (8), 1596-1606.

(2) Kumar, S.; Karthikeyan, S.; Lee, A. F. g- $\mathrm{C}_{3} \mathrm{~N}_{4}$-Based Nanomaterials for Visible Light-Driven Photocatalysis. Catalysts 2018, 8 (2), 74.

(3) Xiao, M.; Luo, B.; Wang, S.; Wang, L. Solar energy conversion on $\mathrm{g}_{-} \mathrm{C}_{3} \mathrm{~N}_{4}$ photocatalyst: Light harvesting, charge separation, and surface kinetics. J. Energy Chem. 2018, 27 (4), 1111-1123.

(4) Wang, X.; Maeda, K.; Chen, X.; Takanabe, K.; Domen, K.; Hou, Y.; Fu, X.; Antonietti, M. Polymer Semiconductors for Artificial Photosynthesis: Hydrogen Evolution by Mesoporous Graphitic Carbon Nitride with Visible Light. J. Am. Chem. Soc. 2009, 131 (5), $1680-1681$

(5) Wang, X.; Maeda, K.; Thomas, A.; Takanabe, K.; Xin, G.; Carlsson, J. M.; Domen, K.; Antonietti, M. A metal-free polymeric photocatalyst for hydrogen production from water under visible light. Nat. Mater. 2009, 8, 76.

(6) Safaei, J.; Mohamed, N. A.; Mohamad Noh, M. F.; Soh, M. F.; Ludin, N. A.; Ibrahim, M. A.; Roslam Wan Isahak, W. N.; Mat Teridi, M. A. Graphitic carbon nitride $\left(\mathrm{g}-\mathrm{C}_{3} \mathrm{~N}_{4}\right)$ electrodes for energy conversion and storage: a review on photoelectrochemical water splitting, solar cells and supercapacitors. J. Mater. Chem. A 2018, 6 (45), 22346-22380.

(7) Shen, M.; Zhang, L.; Wang, M.; Tian, J.; Jin, X.; Guo, L.; Wang, L.; Shi, J. Carbon-vacancy modified graphitic carbon nitride: enhanced $\mathrm{CO}_{2}$ photocatalytic reduction performance and mechanism probing. J. Mater. Chem. A 2019, 7 (4), 1556-1563.

(8) Zheng, Y.; Liu, J.; Liang, J.; Jaroniec, M.; Qiao, S. Z. Graphitic carbon nitride materials: controllable synthesis and applications in fuel cells and photocatalysis. Energy Environ. Sci. 2012, 5, 6717-6731.

(9) Mansor, N.; Jorge, A. B.; Corà, F.; Gibbs, C.; Jervis, R.; McMillan, P. F.; Wang, X.; Brett, D. J. L. Graphitic Carbon Nitride Supported Catalysts for Polymer Electrolyte Fuel Cells. J. Phys. Chem. C 2014, 118 (13), 6831-6838.

(10) Wang, Y.; Wang, X.; Antonietti, M. Polymeric Graphitic Carbon Nitride as a Heterogeneous Organocatalyst: From Photo- chemistry to Multipurpose Catalysis to Sustainable Chemistry. Angew. Chem., Int. Ed. 2012, 51 (1), 68-89.

(11) Haque, E.; Jun, J. W.; Talapaneni, S. N.; Vinu, A.; Jhung, S. H. Superior adsorption capacity of mesoporous carbon nitride with basic CN framework for phenol. J. Mater. Chem. 2010, 20 (48), 1080110803.

(12) Lee, S. P. Synthesis and Characterization of Carbon Nitride Films for Micro Humidity Sensors. Sensors 2008, 8 (3), 1508-1518.

(13) Zhang, J.; Sun, J.; Maeda, K.; Domen, K.; Liu, P.; Antonietti, M.; Fu, X.; Wang, X. Sulfur-mediated synthesis of carbon nitride: Band-gap engineering and improved functions for photocatalysis. Energy Environ. Sci. 2011, 4 (3), 675-678.

(14) Roy, S.; Reisner, E. Visible-light driven $\mathrm{CO}_{2}$ reduction by mesoporous carbon nitride modified with polymeric cobalt phthalocyanine. Angew. Chem., Int. Ed. 2019, 58, 12180-12184.

(15) Molina, B.; Sansores, L. E. Electronic Structure of Six Phases of $\mathrm{C}_{3} \mathrm{~N}_{4}$ : A theoretical Approach. Mod. Phys. Lett. B 1999, 13 (06n07), 193-201.

(16) Hawecker, J.; Lehn, J.-M.; Ziessel, R. Photochemical Reduction of Carbon Dioxide to Formate Mediated by Ruthenium Bipyridine Complexes as Homogeneous Catalysts. J. Chem. Soc., Chem. Commun. 1985, No. 2, 56-58.

(17) Hawecker, J.; Lehn, J.-M.; Ziessel, R. Photochemical and Electrochemical Reduction of Carbon Dioxide to Carbon Monoxide Mediated by (2,2'-bipyridine)tricarbonylchlororhenium(I) and Related Complexes as Homogeneous Catalysts. Helv. Chim. Acta 1986, 69 (8), 1990-2012.

(18) Lehn, J.-M.; Ziessel, R. Photochemical Generation of Carbon Monoxide and Hydrogen by Reduction of Carbon Dioxide and Water under Visible Light Irradiation. Proc. Natl. Acad. Sci. U. S. A. 1982, 79 (2), 701-704.

(19) Rao, H.; Bonin, J.; Robert, M. Non-sensitized Selective Photochemical Reduction of $\mathrm{CO}_{2}$ to $\mathrm{CO}$ under Visible Light with an Iron Molecular Catalyst. Chem. Commun. 2017, 53, 2830-2833.

(20) Rao, H.; Bonin, J.; Robert, M. Toward Visible-Light Photochemical $\mathrm{CO}_{2}$-to- $\mathrm{CH}_{4}$ Conversion in Aqueous Solutions Using Sensitized Molecular Catalysis. J. Phys. Chem. C 2018, 122 (25), 13834-13839.

(21) Rao, H.; Lim, C.-H.; Bonin, J.; Miyake, G. M.; Robert, M. Visible-Light-Driven Conversion of $\mathrm{CO}_{2}$ to $\mathrm{CH}_{4}$ with an Organic Sensitizer and an Iron Porphyrin Catalyst. J. Am. Chem. Soc. 2018, 140 (51), 17830-17834.

(22) Rao, H.; Schmidt, L. C.; Bonin, J.; Robert, M. Visible-lightdriven Methane Formation from $\mathrm{CO}_{2}$ with a Molecular Iron Catalyst. Nature 2017, 548, 74-77.

(23) Dalle, K. E.; Warnan, J.; Leung, J. J.; Reuillard, B.; Karmel, I. S.; Reisner, E. Electro- and Solar-Driven Fuel Synthesis with First Row Transition Metal Complexes. Chem. Rev. 2019, 119 (4), 2752-2875.

(24) Takeda, H.; Cometto, C.; Ishitani, O.; Robert, M. Electrons, Photons, Protons and Earth-Abundant Metal Complexes for Molecular Catalysis of $\mathrm{CO}_{2}$ Reduction. ACS Catal. 2017, 7, 70-88.

(25) Neri, G.; Forster, M.; Walsh, J. J.; Robertson, C. M.; Whittles, T. J.; Farràs, P.; Cowan, A. J. Photochemical $\mathrm{CO}_{2}$ reduction in water using a co-immobilised nickel catalyst and a visible light sensitiser. Chem. Commun. 2016, 52 (99), 14200-14203.

(26) Kuehnel, M. F.; Sahm, C. D.; Neri, G.; Lee, J. R.; Orchard, K. L.; Cowan, A. J.; Reisner, E. ZnSe quantum dots modified with a $\mathrm{Ni}$ (cyclam) catalyst for efficient visible-light driven $\mathrm{CO}_{2}$ reduction in water. Chem. Sci. 2018, 9 (9), 2501-2509.

(27) Walsh, J. J.; Jiang, C.; Tang, J.; Cowan, A. J. Photochemical $\mathrm{CO}_{2}$ reduction using structurally controlled $\mathrm{g}-\mathrm{C}_{3} \mathrm{~N}_{4}$. Phys. Chem. Chem. Phys. 2016, 18 (36), 24825-24829.

(28) Maeda, K. Metal-Complex/Semiconductor Hybrid Photocatalysts and Photoelectrodes for $\mathrm{CO}_{2}$ Reduction Driven by Visible Light. Adv. Mater. 2019, 31 (25), 1808205.

(29) Kuriki, R.; Maeda, K. Development of hybrid photocatalysts constructed with a metal complex and graphitic carbon nitride for visible-light-driven $\mathrm{CO}_{2}$ reduction. Phys. Chem. Chem. Phys. 2017, 19 (7), 4938-4950. 
(30) Maeda, K.; Sekizawa, K.; Ishitani, O. A polymeric-semiconductor-metal-complex hybrid photocatalyst for visible-light $\mathrm{CO}_{2}$ reduction. Chem. Commun. 2013, 49 (86), 10127-10129.

(31) Kuriki, R.; Ishitani, O.; Maeda, K. Unique Solvent Effects on Visible-Light $\mathrm{CO}_{2}$ Reduction over Ruthenium(II)-Complex/Carbon Nitride Hybrid Photocatalysts. ACS Appl. Mater. Interfaces 2016, 8 (9), 6011-6018.

(32) Kuriki, R.; Yamamoto, M.; Higuchi, K.; Yamamoto, Y.; Akatsuka, M.; Lu, D.; Yagi, S.; Yoshida, T.; Ishitani, O.; Maeda, K. Robust Binding between Carbon Nitride Nanosheets and a Binuclear Ruthenium(II) Complex Enabling Durable, Selective $\mathrm{CO}_{2}$ Reduction under Visible Light in Aqueous Solution. Angew. Chem., Int. Ed. 2017, 56 (17), 4867-4871.

(33) Maeda, K.; Kuriki, R.; Ishitani, O. Photocatalytic Activity of Carbon Nitride Modified with a Ruthenium(II) Complex Having Carboxylic- or Phosphonic Acid Anchoring Groups for Visible-light $\mathrm{CO}_{2}$ Reduction. Chem. Lett. 2016, 45 (2), 182-184.

(34) Kasap, H.; Caputo, C. A.; Martindale, B. C. M.; Godin, R.; Lau, V. W.-h.; Lotsch, B. V.; Durrant, J. R.; Reisner, E. Solar-Driven Reduction of Aqueous Protons Coupled to Selective Alcohol Oxidation with a Carbon Nitride-Molecular Ni Catalyst System. J. Am. Chem. Soc. 2016, 138 (29), 9183-9192.

(35) Lin, J.; Pan, Z.; Wang, X. Photochemical Reduction of $\mathrm{CO}_{2}$ by Graphitic Carbon Nitride Polymers. ACS Sustainable Chem. Eng. 2014, 2 (3), 353-358.

(36) Zhang, J.-S.; Zhang, W.-D. Superior Photocatalytic Generation of $\mathrm{H}_{2}$ in Water Medium Through Grafting a Cobalt Molecule CoCatalyst from Carbon Nitride Nanosheets. ChemCatChem 2019, 11 (11), 2657-2666.

(37) Kuriki, R.; Sekizawa, K.; Ishitani, O.; Maeda, K. Visible-LightDriven $\mathrm{CO}_{2}$ Reduction with Carbon Nitride: Enhancing the Activity of Ruthenium Catalysts. Angew. Chem., Int. Ed. 2015, 54 (8), 24062409.

(38) Cometto, C.; Kuriki, R.; Chen, L.; Maeda, K.; Lau, T.-C.; Ishitani, O.; Robert, M. A Carbon Nitride/Fe Quaterpyridine Catalytic System for Photostimulated $\mathrm{CO}_{2}$-to- $\mathrm{CO}$ Conversion with Visible Light. J. Am. Chem. Soc. 2018, 140 (24), 7437-7440.

(39) Guo, Z.; Cheng, S.; Cometto, C.; Anxolabéhère-Mallart, E.; Ng, S.-M.; Ko, C.-C.; Liu, G.; Chen, L.; Robert, M.; Lau, T.-C. Highly Efficient and Selective Photocatalytic $\mathrm{CO}_{2}$ Reduction by Iron and Cobalt Quaterpyridine Complexes. J. Am. Chem. Soc. 2016, 138 (30), 9413-9416.

(40) Maeda, K.; Kuriki, R.; Zhang, M.; Wang, X.; Ishitani, O. The effect of the pore-wall structure of carbon nitride on photocatalytic $\mathrm{CO}_{2}$ reduction under visible light. J. Mater. Chem. A 2014, 2 (36), 15146-15151.

(41) Miller, T. S.; Jorge, A. B.; Suter, T. M.; Sella, A.; Corà, F.; McMillan, P. F. Carbon nitrides: synthesis and characterization of a new class of functional materials. Phys. Chem. Chem. Phys. 2017, 19 (24), 15613-15638.

(42) Bonin, J.; Chaussemier, M.; Robert, M.; Routier, M. Homogeneous Photocatalytic Reduction of $\mathrm{CO}_{2}$ to $\mathrm{CO}$ Using Iron(0) Porphyrin Catalysts: Mechanism and Intrinsic Limitations. ChemCatChem 2014, 6 (11), 3200-7.

(43) Bonin, J.; Robert, M.; Routier, M. Selective and Efficient Photocatalytic $\mathrm{CO}_{2}$ Reduction to $\mathrm{CO}$ Using Visible Light and an Iron-Based Homogeneous Catalyst. J. Am. Chem. Soc. 2014, 136 (48), 16768-16771.

(44) Lam, K.-M.; Wong, K.-Y.; Yang, S.-M.; Che, C.-M. Cobalt and nickel complexes of $2,2^{\prime}: 6^{\prime}, 2^{\prime \prime}: 6^{\prime \prime}, 2^{\prime \prime \prime}$-quaterpyridine as catalysts for electrochemical reduction of carbon dioxide. J. Chem. Soc., Dalton Trans. 1995, No. 7, 1103-1107.

(45) Kuriki, R.; Ranasinghe, C. S. K.; Yamazaki, Y.; Yamakata, A.; Ishitani, O.; Maeda, K. Excited-State Dynamics of Graphitic Carbon Nitride Photocatalyst and Ultrafast Electron Injection to a $\mathrm{Ru}(\mathrm{II})$ Mononuclear Complex for Carbon Dioxide Reduction. J. Phys. Chem. C 2018, 122 (29), 16795-16802.

(46) Yang, W.; Godin, R.; Kasap, H.; Moss, B.; Dong, Y.; Hillman, S. A. J.; Steier, L.; Reisner, E.; Durrant, J. R. Electron Accumulation
Induces Efficiency Bottleneck for Hydrogen Production in Carbon Nitride Photocatalysts. J. Am. Chem. Soc. 2019, 141 (28), 1121911229.

(47) Song, Z.; Li, Z.; Lin, L.; Zhang, Y.; Lin, T.; Chen, L.; Cai, Z.; Lin, S.; Guo, L.; Fu, F.; Wang, X. Phenyl-doped graphitic carbon nitride: photoluminescence mechanism and latent fingerprint imaging. Nanoscale 2017, 9 (45), 17737-17742.

(48) Huang, P.; Huang, J.; Pantovich, S. A.; Carl, A. D.; Fenton, T. G.; Caputo, C. A.; Grimm, R. L.; Frenkel, A. I.; Li, G. Selective $\mathrm{CO}_{2}$ Reduction Catalyzed by Single Cobalt Sites on Carbon Nitride under Visible-Light Irradiation. J. Am. Chem. Soc. 2018, 140 (47), 1604216047.

(49) Lee, I.-S. H.; Jeoung, E. H.; Kreevoy, M. M. Marcus Theory of a Parallel Effect on $\alpha$ for Hydride Transfer Reaction between NAD+ Analogues. J. Am. Chem. Soc. 1997, 119 (11), 2722-2728.

(50) Guo, Z.; Chen, G.; Cometto, C.; Ma, B.; Zhao, H.; Groizard, T.; Chen, L.; Fan, H.; Man, W.-L.; Yiu, S.-M.; Lau, K.-C.; Lau, T.-C.; Robert, M. Selectivity control of $\mathrm{CO}$ versus $\mathrm{HCOO}^{-}$production in the visible-light-driven catalytic reduction of $\mathrm{CO}_{2}$ with two cooperative metal sites. Nature Catal. 2019, 2, 801-808. 